\title{
IMPLEMENTASI METODE EXTREME PROGRAMMING UNTUK MERANCANG SISTEM INFORMASI PENDAFTARAN SISWA BARU BERBASIS WEB PADA SMK MULTIMEDIA MANDIRI JAKARTA Yusnia Budiarti ${ }^{1)}$
}

Teknik Informatika, STMIK Nusa Mandiri Jakarta

Email: yusnia.ybi@nusamandiri.ac.id

$$
\text { Risyanto }^{2)}
$$

Sistem Informasi, Universitas Bina Sarana Informatika Email: risyanto47@gmail.com

\begin{abstract}
Abstraksi
Dikembangkannya sistem penerimaan siswa baru secara online di sekolah-sekolah diharapkan akan membuat pelaksanaan penerimaan siswa baru menjadi lebih transparan, efektif, dan efisien. Sistem ini akan menjadikan proses pendataan dan administrasi lebih mudah, cepat, efisien, baik dalam hal waktu, tempat, biaya, maupun tenaga. Tak ketinggalan juga, dengan sistem ini para peserta dan orang tua peserta tidak perlu bersusah payah mendatangi sekolah untuk sekedar melihat pengumuman atau informasi yang berkaitan dengan pelaksanaan penerimaan siswa baru. SMK Multimedia Mandiri adalah sekolah swasta yang saat ini masih menggunakan sistem pendaftaran siswa baru secara manual, dimana calon siswa harus datang langsung ke sekolah untuk mendaftarkan diri serta banyak terjadi masalah seperti tidak terbacanya tulisan tangan calon siswa baru yang menyebabkan kesalahan data siswa serta hilangnya dokumen-dokumen penting pendaftaran siswa di sekolah karna tidak didokumentasikan dengan baik. penulis meneliti sistem pendaftaran siswa baru yang sedang berjalan di SMK Multimedia Mandiri dan mengajukan sistem pendaftaran siswa baru berbasis web yang diharapkan dapat menjadi solusi dari masalah-masalah tersebut. Dalam penelitian ini penulis menggunakan metode extreme programming untuk merancang sistemnya.
\end{abstract}

\section{Kata Kunci: Perancangan Sistem, Pendaftaran Siswa Baru, Metode Extreme Programming}

\begin{abstract}
The development of an online student admission system in schools is expected to make the implementation of new student admissions more transparent, effective and efficient. This system will make the data collection and administration process easier, faster, more efficient, both in terms of time, place, cost and energy. with this system the participants and parents do not have to bother going to school to just see announcements or information relating to the implementation of new student admissions. SMK Multimedia Mandiri is a private school that is currently still using the new student registration system manually, where prospective students must come directly to the school to register and there are many problems such as unreadable handwriting of prospective new students which causes student data errors and loss of documents- Important documents on student registration at school are not well documented. The author examines the new student registration system currently running at SMK Multimedia Mandiri and proposes a web-based new student registration system that is expected to be a solution of these problems. In this study the authors used the extreme programming method to design the system.
\end{abstract}

Keywords: Development system, Registration new students, extreme programming methode 


\section{I.PENDAHULUAN}

Indeks Pembangunan Teknologi Informasi dan Komunikasi (IPTIK) Indonesia di tahun 2018 sebesar 4,34 dengan skala $0-10$, meningkat dibanding IPTIK tahun 2015 sebesar 3,88 (www.bps.go.id). Hal ini menunjukan semakin berkembangnya penggunaan internet dari tahun ke tahun, sehingga masyarakat bisa memanfaatkannya untuk kegiatan sehari-hari seperti pendidikan, komunikasi secara cepat, untuk menambah wawasan, belanja online, sebagai bisnis, dan lain-lain. Diantaranya manfaat internet juga digunakan sebagai sarana untuk pendaftaran siswa baru secara online yang mampu mendukung proses input dan output data secara cepat dan akurat.

Pada saat ini sering dibutuhkan alat yang mempunyai kemampuan untuk melakukan pekerjaan rutin, menghitug, menyimpan informasi dalam jumlah besar, mengambil data dengan cepat secara acak (random) maupun urut (sequential) dan menyelseaikan persoalan yang sangat rumit serta banyak perhitungan dalam waktu yang cepat. Dalam hal ini komputer merupakan alat yang memainkan peranan yang sangat besar. Kehadiran komputer didalam suatu organisasi atau sekolah akan menunjang efisiensi kinerja sehingga akan mendapatkan dampak yang positif didalam suatu aktifitas sekolah (Ruhul Amin, 2017)

Pendaftaran merupakan langkah awal dalam masuk atau bergabung dalam suatu instansi. Selain itu pendaftaran merupakan suatu proses administrasi yang terjadi setiap tahun untuk seleksi peserta didik baru berdasarkan nilai akademik agar dapat melanjutkan pendidikan pada jenjang yang lebih tinggi (Fatimah, Setiawan, \& Pantjarani, 2016).

Menurut (Putri, 2014) Selama ini proses pendaftaran siswa baru masih menggunakan cara yang manual yaitu dengan pengisian formulir menggunakan lembaran yang disediakan oleh panitia, karena menggunakan tulisan tangan akan memungkinkan panitia kesulitan dalam membaca. Selain itu dalam proses pembuatan laporan seleksi penerimaan siswa baru memakan waktu yang lebih lama, hal ini dapat menyebabkan lambatnya informasi pengumuman bagi peserta.

Pengelolaan data penerimaan siswa baru masih dilakukan secara manual dan pembayaran uang pendaftaran dan uang daftar ulang masih dilakukan secara bersamaan saat pendaftaran. Dimana pendaftaran tersebut dilakukan dengan cara mendatangi langsung sekolah, Hal ini sangat tidak efektif dari segi waktu dan tenaga (Eviani, Rizki, \& Pratiwi, 2016).

SMK Multimedia Mandiri merupakan salah satu yayasan pendidikan formal untuk mendidik anak-anak setingkat Sekolah Menengah Kejuruan (SMK). Saat ini proses penerimaan siswa baru dilakukan dengan cara membuka stand dan membagikan formulir pendaftaran siswa baru yang berminat dan mengikuti tahap-tahap selanjutnya sehingga sangat memakan banyak waktu. Semakin meluasnya jaringan internet diharapkan dapat menjadi salah satu solusi untuk mengatasi masalah-masalah yang terjadi pada SMK Multimedia Mandiri Jakarta dengan dirancangnya Sistem informasi pendaftaran siswa baru berbasis web. Metode yang digunakan untuk merancang system adalah extreme programming $(x p)$ yaitu metode pengembangan software berdasarkan prinsip kesederhanaan, komunikasi, dan umpan balik yang baik. XP dirancang untuk digunakan dengan tim kecil yang membutuhkan untuk mengembangkan perangkat lunak dengan cepat dalam lingkungan yang cepat berubah pula (Candra, Muludi, \& Irawati, 2013). Serta menggunakan UML sebagai tools untuk merancang sistem.

Menurut (Witanto \& Solihin, 2015) Sistem yang masih konvensional ini juga mengakibatkan proses administrasi penerimaan siswa baru cenderung lambat, karena data siswa baru yang telah mendaftar belum terintegrasi dan terkelola dengan baik. Sistem ini juga masih menggunakan arsip dalam bentuk fisik yang rentan mengalami kerusakan atau bahkan hilang. Sehingga kebutuhan akan suatu konsep dan mekanisme penerimaan siswa baru dengan memanfaatkan teknologi informasi menjadi hal yang perlu dipertimbangkan. 


\section{II.LANDASAN TEORI}

Unified Modelling Language (UML)

Menurut (Mulyani, 2016) Unified Modelling Language adalah sebuah teknik pengembangan sistem yang menggunakan bahasa grafis sebagai alat untuk pendokumentasian dan melakukan spesifikasi pada sistem - beberapa jenis diagram pada UML diantaranya adalah (Sukamto \& Shalahudin, 2013):

1. Activity Diagram menggambarkan work flow (aliran kerja) atau aktifitas dari sebuah sistem atau proses bisnis atau menu yang ada pada perangkat lunak. Activity Diagram menggambarkan aktivitas sistem bukan apa yang dilakukan actor.

2. Use Case Diagram merupakan pemodelan untuk kelakuan (behavior) sistem informasi yang akan dibuat. Use case mendeskripsikan sebuah interaksi antara satu atau lebih aktor. Tujuan use case adalah memetakkan kebutuhan sistem dan merepresentasikan interaksi pengguna terhadap sistem.

3. Component Diagram merupakan Komponen terhubung melalui antarmuka yang digunakan dan dibutuhkan, sering menggunakan notasi bola dan soket seperti halnya class diagram.

4. Deplyopment diagram menunjukkan susunan fisik sebuah sistem, menunjukkan bagian perangkat lunak mana yang berjalan pada perangkat keras mana.

\section{METODE PENELITIAN \\ Tehnik Pengumpulan Data}

1. Observasi : Penulis mencari dan mengumpulkan data dengan cara mengamati secara langsung proses penerimaan siswa baru pada Sekolah Menengah Kejuruan yang diadakan oleh panitia Pendaftaran Peserta Didik Baru (PPDB)

2. Wawancara : Penulis melakukan tanya jawab secara langsung kepada Ibu Urfy selaku Wakil Kepala Sekolah dan Bapak Slamet Riyanto selaku kepala sekolah SMK Multimedia Mandiri.

3. Studi pustaka : Penulis mencari dan mengutip informasi dari sumber referensi yang ada seperti, buku-buku tentang website dan sistem, jurnal megenai sistem pendaftaran online dan semua sumber referensi serta artikel ilmiah terkait lainnya yang menunjang penulisan

\section{Metode Extreme Programming (XP)}

Metode Extreme Programming sering juga dikenal dengan metode XP. Metode ini dicetuskan oleh Kent Beck, seorang pakar software engineering. Extreme programming adalah model pengembangan perangkat lunak yang menyederhanakan berbagai tahapan pengembangan sistem menjadi lebih efisien, adaptif dan fleksibel. Nilai dasar metode extreme programming (Fatoni \& Dwi, 2016) :

1. Communication : Memfokuskan komunikasi yang baik antara programmer dengan user maupun antar programmer.

2. Courage: Pengembang perangkat lunak harus selalu memiliki keyakinan, keberanian dan integritas dalam melakukan tugasnya.

3. Simplicity: Lakukan semua dengan sederhana.

4. Feedback: Mengandalkan feedback sehingga dibutuhkan anggota tim yang berkualitas.

5. Quality Work: Proses berkualitas berimplikasi pada perangkat lunak yang berkualitas sebagai hasil akhirnya.

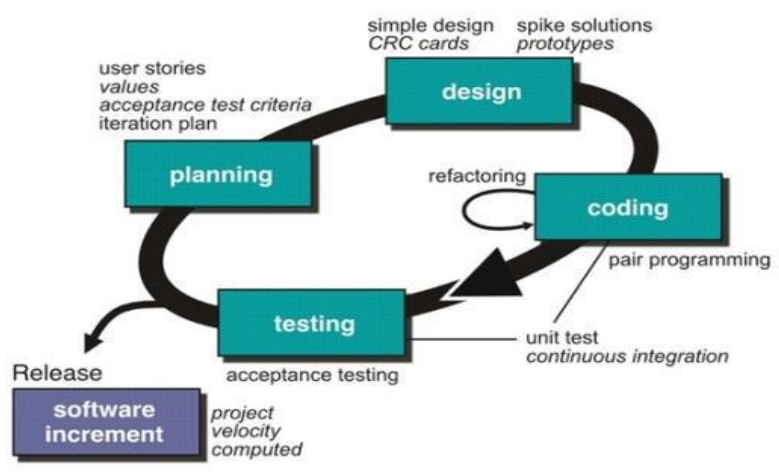

Gambar 1. Tahapan Metode extreme programming (Fatoni \& Dwi, 2016) 
Tahapan-tahapan metode extreme programming menurut (Supriyatna, 2018)

1. Planning (Perencanaan)

Tahapan ini dimulai dengan mendengarkan kumpulan kebutuhan aktifitas suatu sistem yang memungkinkan pengguna memahami proses bisnis untuk sistem dan mendapatkan gambaran yang jelas mengenai fitur utama, fungsionalitas dan keluaran yang diinginkan. Dalam perancangan sistem informasi pendaftaran siswa baru pada tahap ini dimulai dari mengidentifikasi permasalahan yang timbul pada sistem yang sedang berjalan, kemudian dilakukan analisa kebutuhan pengguna terhadap sistem yang akan dibangun.

2. Design (Perancangan)

Pada tahapan perancangan dilakukan pembuatan pemodelan sistem berdasarkan hasil analisa kebutuhan yang didapatkan. Lalu dibuatkan model basis data untuk menggambarkan hubungan antar data. Pemodelan sistem yang digunakan yaitu Unified Modelling Language (UML) yang terdiri dari UseCase Diagram, Activity Diagram Sedangkan untuk pemodelan basis data menggunakan Entity Relationship Diagram (ERD) dan Logical Record Structure (LRS).

3. Coding (Pengkodean)

Tahapan ini merupakan implementasi dari perancangan model sistem yang telah dibuat kedalam kode program yang menghasilkan prototipe dari perangkat lunak. Dalam pembangunan system informasi pendaftaran siswa baru menggunakan bahasa pemrograman PHP, HTML, CSS dan Javascript. Sedangkan untuk implementasi basis data, Database Management System yang digunakan adalah MySQL.

4. Testing (Pengujian)

Tahapan ini merupakan tahapan pengujian terhadap aplikasi yang sudah dibangun, pada tahapan ini ditentukan oleh pengguna sistem dan berfokus pada fitur dan fungsionalitas dari keseluruhan sistem kemudian ditinjau oleh pengguna sistem. Metode yang digunakan dalam melakukan pengujian terhadap aplikasi web pendaftaran siswa baru adalah Black-Box Testing dengan melakukan pengujian terhadap masukkan dan keluaran yang dihasilkan sistem.

5. Software Increment (Peningkatan Perangkat Lunak)

Tahapan ini merupakan tahap pengembangan sistem yang sudah dibuat secara bertahap dan dilakukan setelah sistem diterapkan dengan menambahkan layanan atau konten yang meningkatkan fungsionalitas dan kinerja dari sistem yang dibuat.

\section{IV.HASIL DAN PEMBAHASAN}

\section{A. Planning (Perencanaan)}

Masalah yang dapat diidentifikasi pada sistem yang sedang berjalan di SMK Multimedia Mandiri adalah:

1. Pendaftaran siswa baru SMK Multimedia Mandiri masih manual menggunakan formulir.

2. Memakan banyak waktu dalam proses pendaftaran karena harus datang langsung ke sekolah.

3. Pengumpulan data calon siswa yang menggunakan formulir beresiko rusak atau hilang serta kesulitan dalam pencarian data ketika dibutuhkan.

4. Calon siswa baru kesulitan mendapatkan informasi mengenai semua hal yang berkaitan dengan proses pendaftaran siswa baru.

Berdasarkan identifikasi masalah yang ada maka dibuatkan Analisa kebutuhan untuk membangun sistem informasi pendaftaran.

Dalam sistem pendaftaran siswa baru secara online terdapat dua pengguna yang dapat saling berinteraksi dalam lingkungan sistem, yaitu: Bagian admin dan Calon Siswa. Kedua pengguna tersebut memiliki karakteristik interaksi dengan sistem yang berbeda-beda dan memiliki kebutuhan informasi yang berbeda-beda, seperti berikut:

1. Calon siswa mengisi formulir pendaftaran dan melengkapi biodata

2. Calon siswa mengupload dokumen persyaratan

3. Calon siswa melakukan konfirmasi pembayaran dengan mengupload bukti 
bayar

4. Calon siswa melihat pengumuman, informasi nilai tes dan pembagian kelas.

5. Calon siswa harus melakukan login terlebih dahulu untuk dapat mengakses aplikasi ini dengan memasukkan nomer pendaftaran dan password agar privasi masing-masing pengguna tetap terjaga keamanannya.

6. Admin mengelola data calon siswa, siswa, data jurusan dan kelas.

7. Admin mengecek data persyaratan calon siswa

8. Admin menginput nilai calon siswa dan kelas

9. Sistem mencetak bukti pendaftaran siswa baru

10. Sistem mengupdate data siswa baru.

\section{B. Design (Perancangan)}

Tahap awal perancangan sistem informasi siswa baru berbasis web ini adalah merancang Use-Case Diagram.

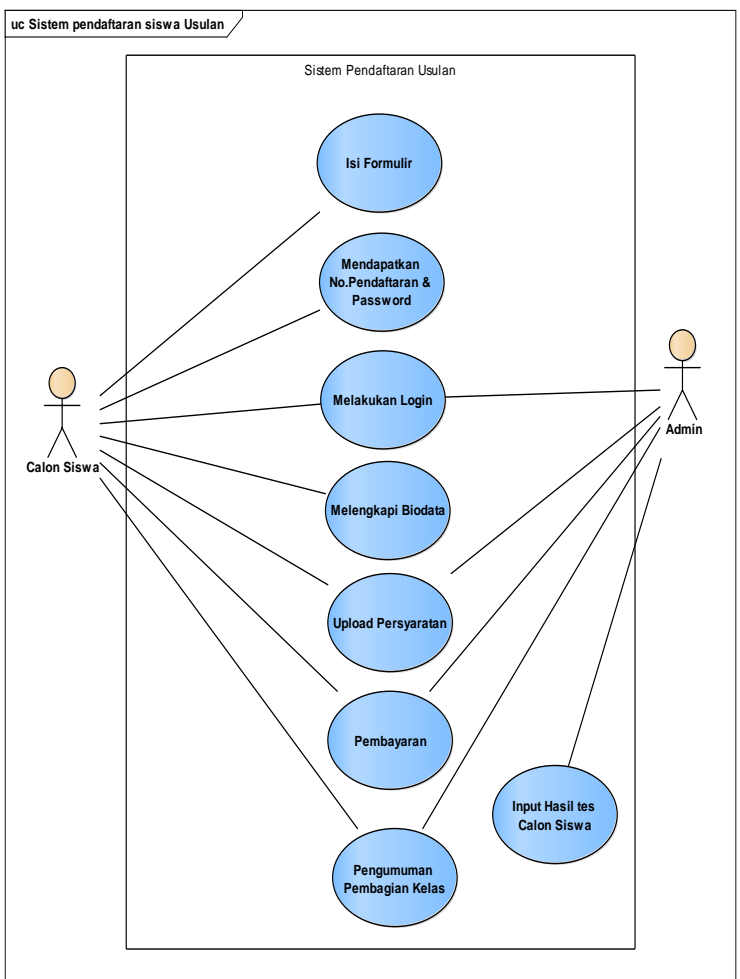

Gambar 2. Use Case Diagram Sistem Informasi Pendaftaran siswa baru
Diagram diatas menggambarkan fungsi dari sistem informasi pendaftaran siswa baru dimana calon siswa dan admin memiliki akses sesuai dengan kebutuhan yang telah dianalisa pada tahap perencanaan.

Tahap design selanjutnya adalah membuat activity diagram

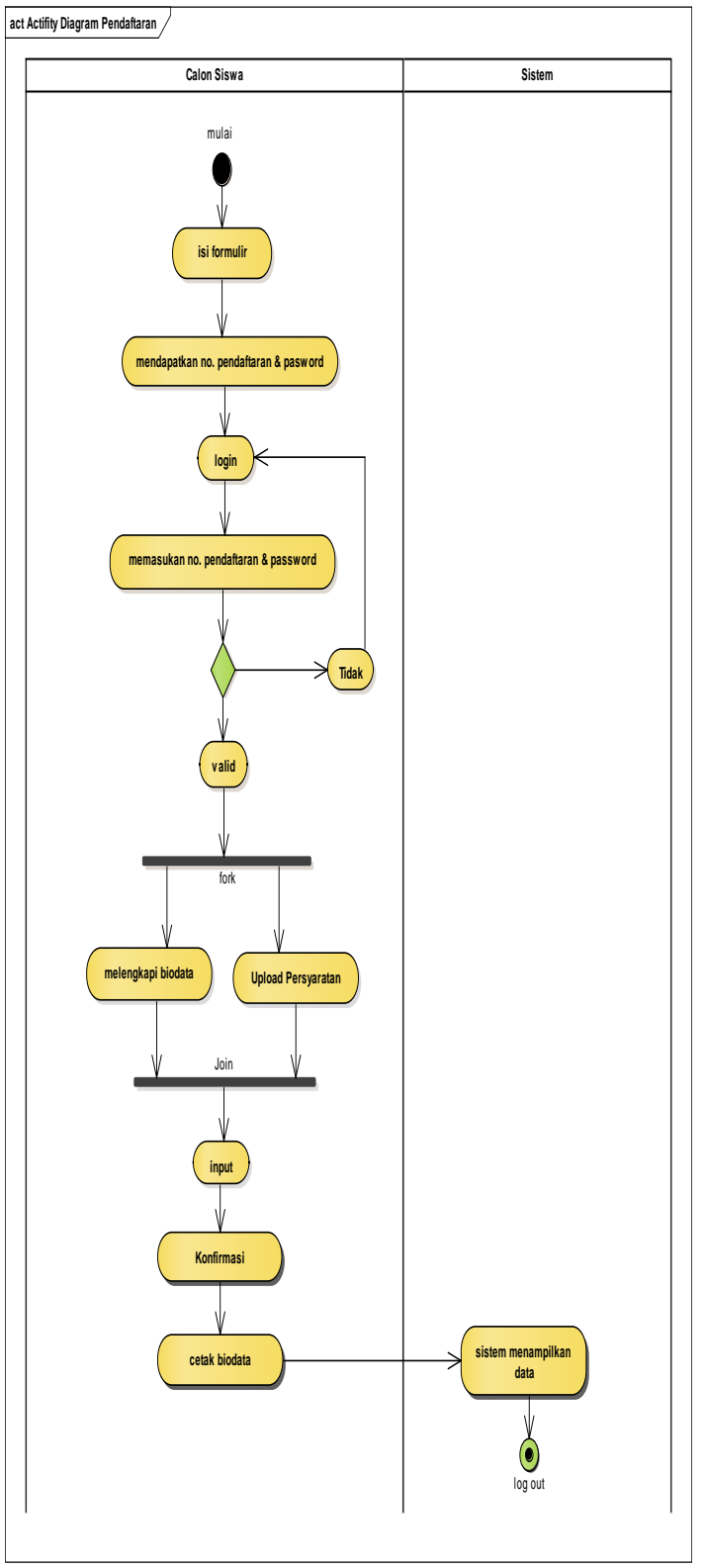

\section{Gambar 3. Activity Diagram Pendaftaran}

Calon siswa yang ingin melakukan pendaftaran membuka menu pendaftaran kemudian sistem menampilkan halaman pendaftaran, calon siswa harus mengisi data

dengan lengkap sesuai dengan elemen data yang 
diminta kemudian klik submit, selanjutnya sistem melakukan validasi kelengkapan data, jika sudah lengkap sistem akan menyimpan data dan konfirmasi pendaftaran melalui email yang berisi username dan password.

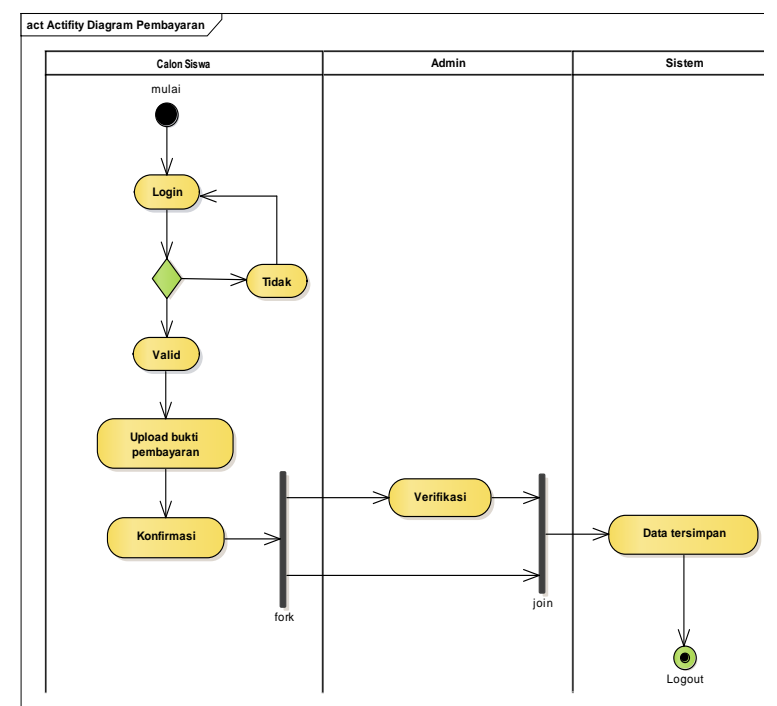

Gambar 4. Activity Diagram Pembayaran

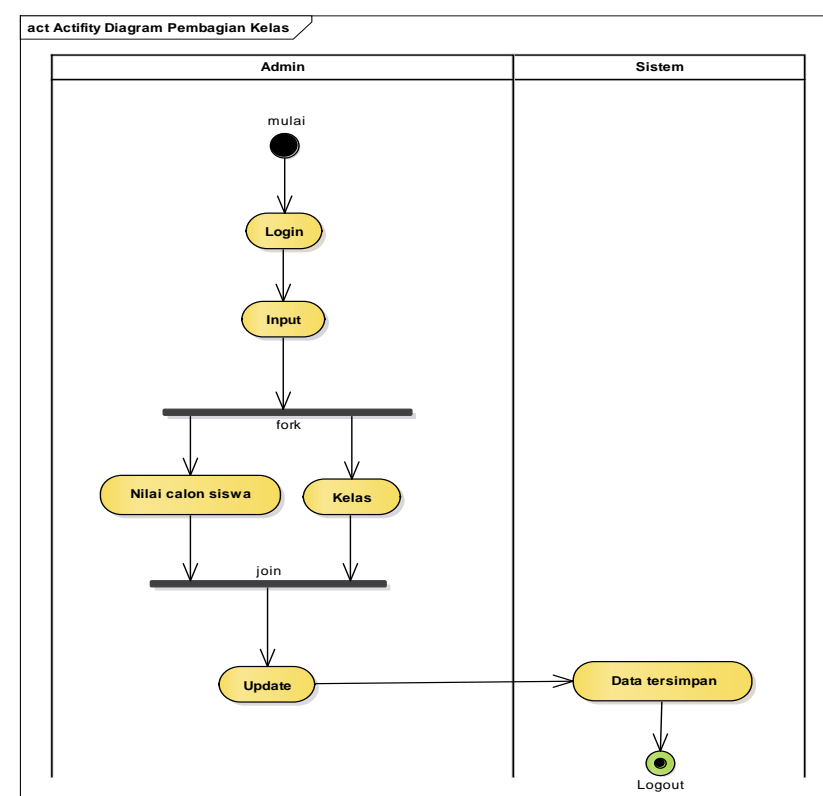

Gambar 5. Activity Diagram Pembagian Kelas

Tahap Perancangan selanjutnya adalah Merancang Basis data menggunakan Entity Relationship Diagram (ERD) dan Logical Record Structure(LRS).

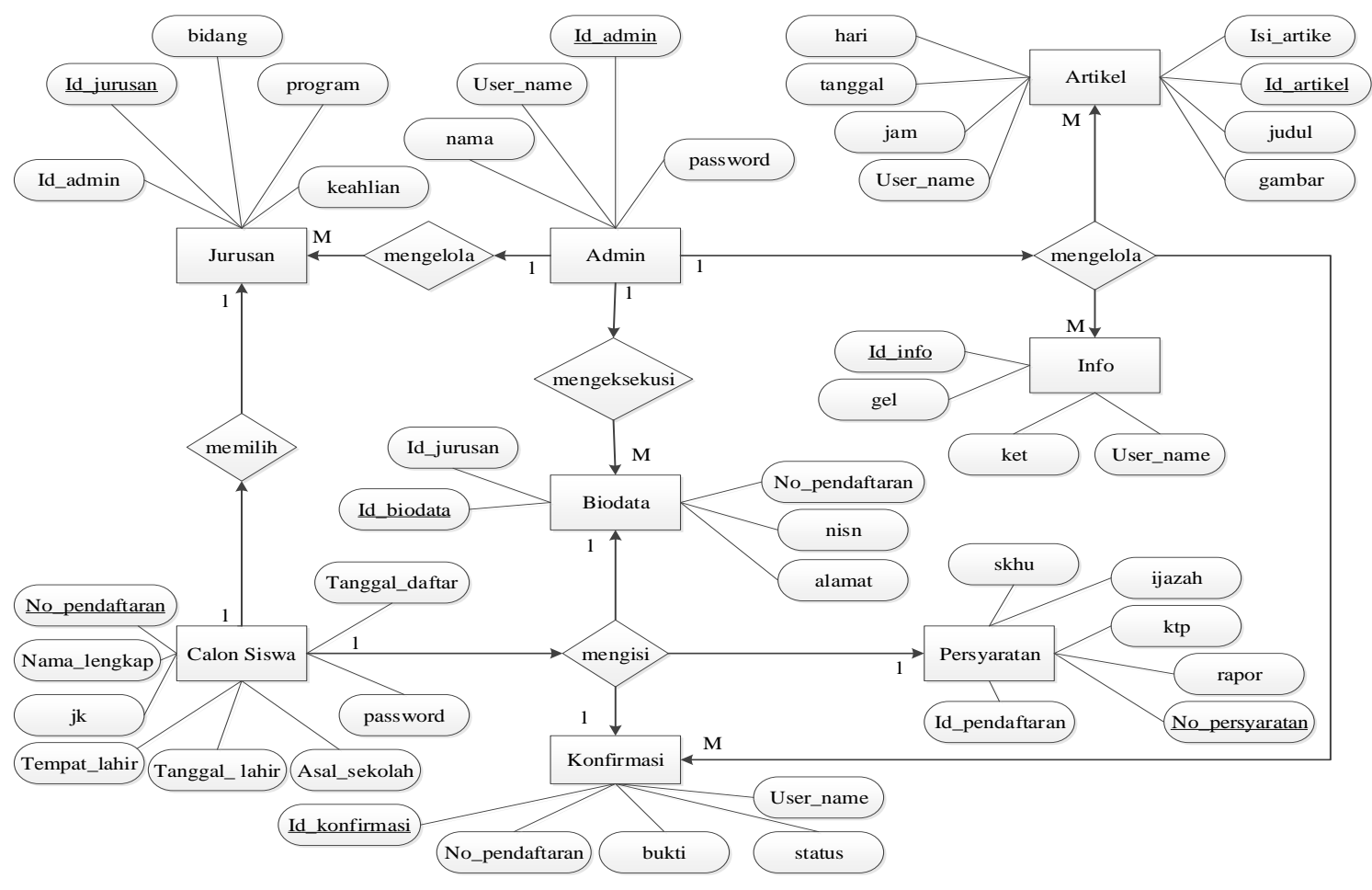

Gambar 6. Entity Relationship Diagram (ERD) 


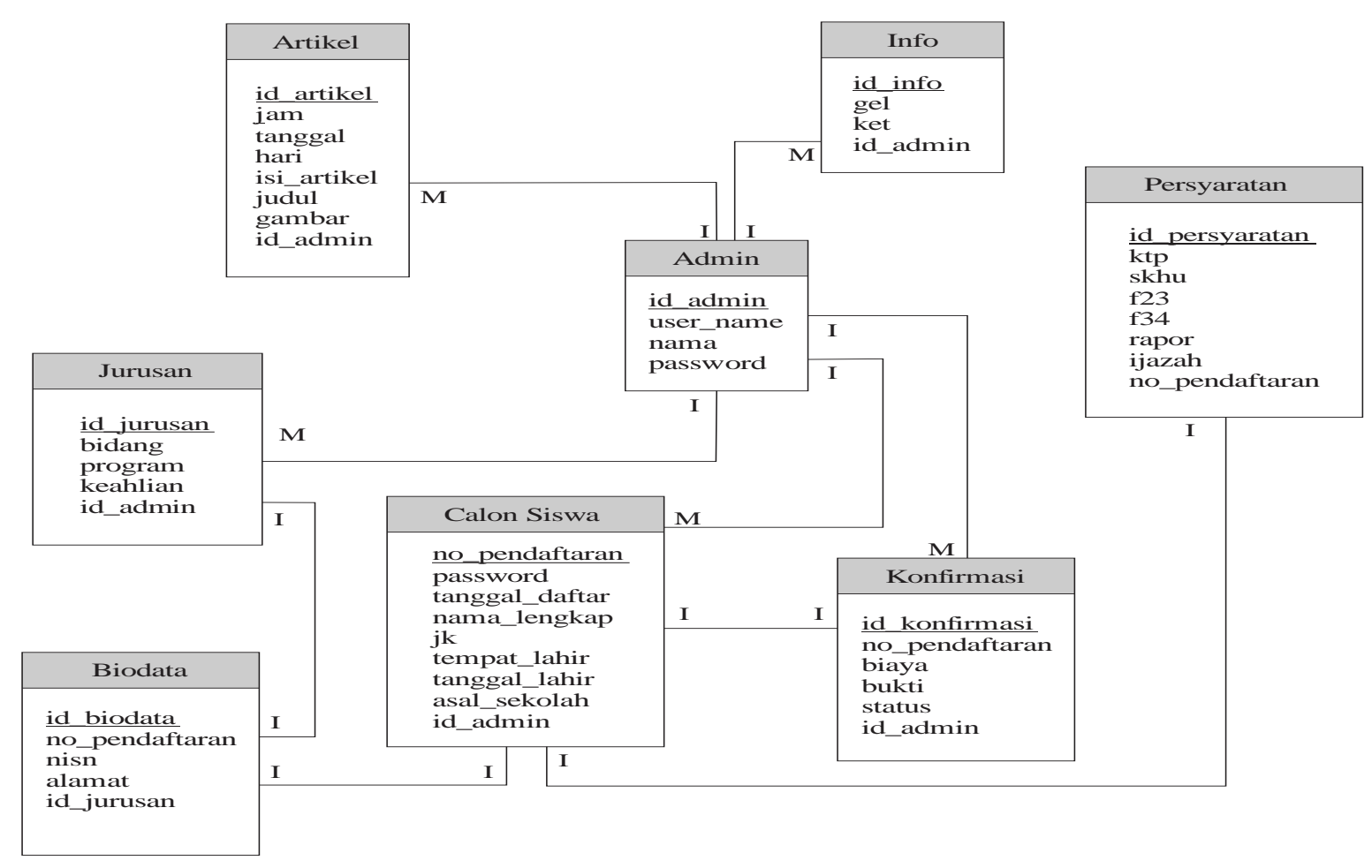

Gambar 7. Logical Record Structure (LRS)

\section{Coding (Pengkodean)}

Tahapan selanjutnya adalah mengimplementasikan rancangan yang telah dibuat kedalam kode program yang selanjutnya menghasilkan prototype program seperti berikut:

1. Halaman Depan
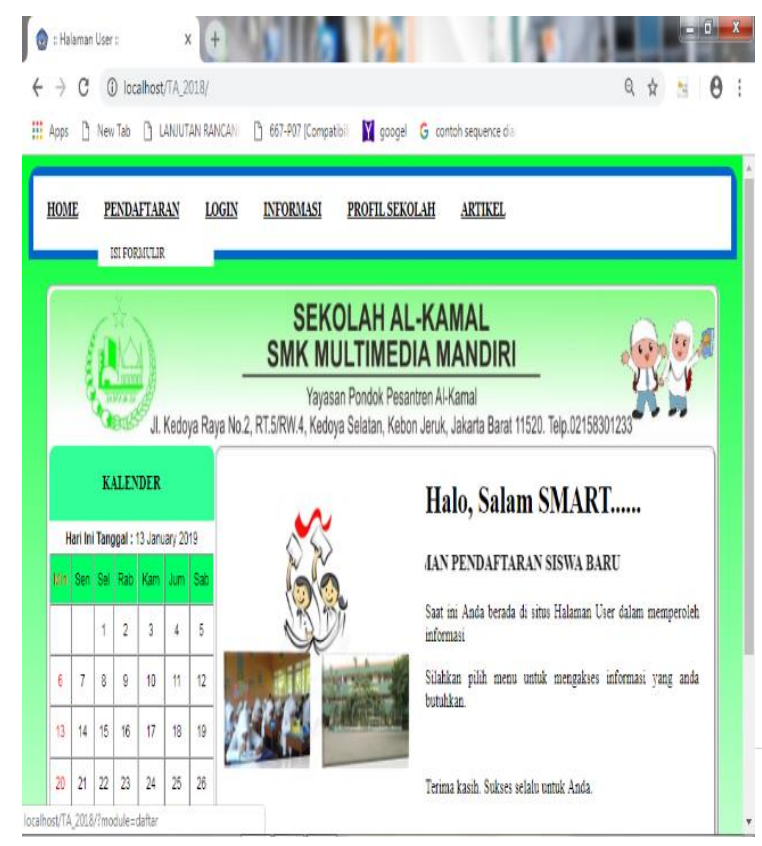

Gambar 8. Tampilan Halaman Home

2. Halaman Formulir Pendaftaran

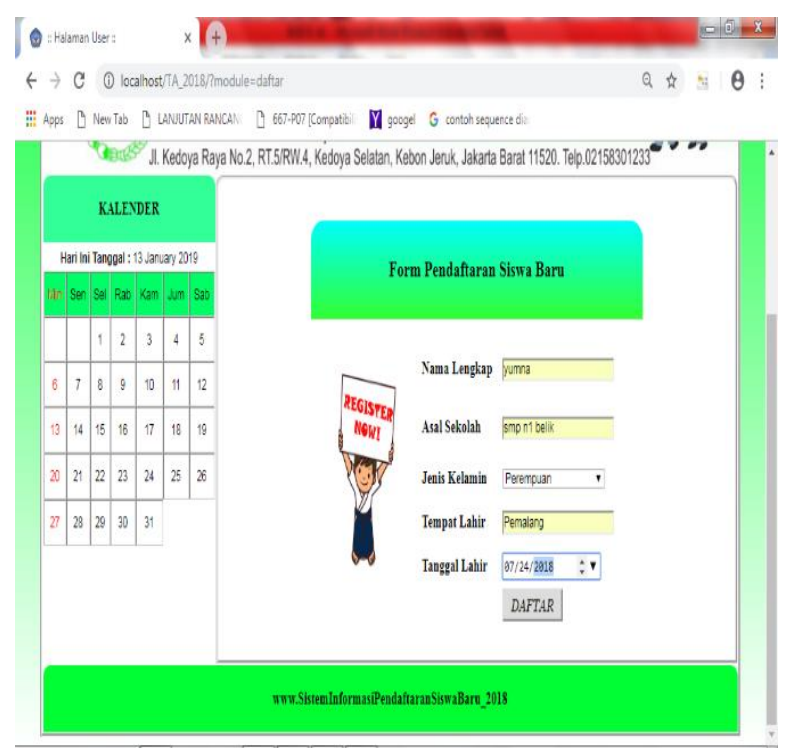

Gambar 9. Halaman Formulir Pendaftaran

$$
\text { 7| P a ge }
$$


3. Halaman Login Calon siswa

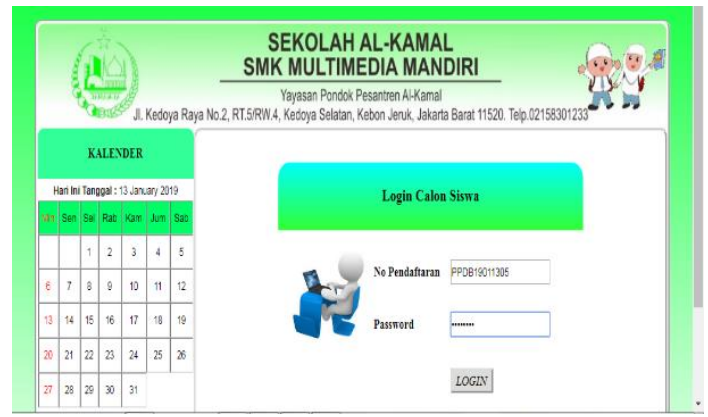

Gambar 10. Halaman Login calon siswa

4. Halaman Cetak Bukti pendaftaran

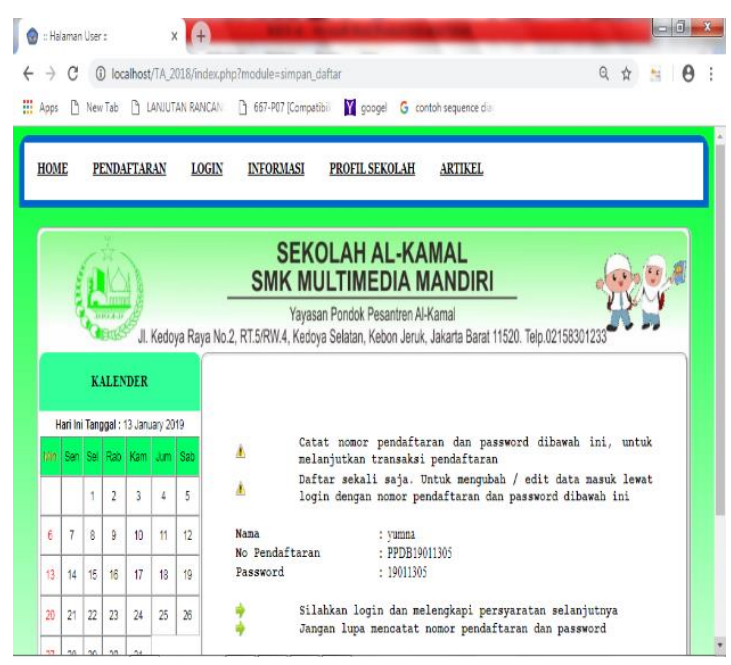

\section{Gambar 11. Hal Cetak Bukti Pendaftaran}

5. Halaman upload persyaratan

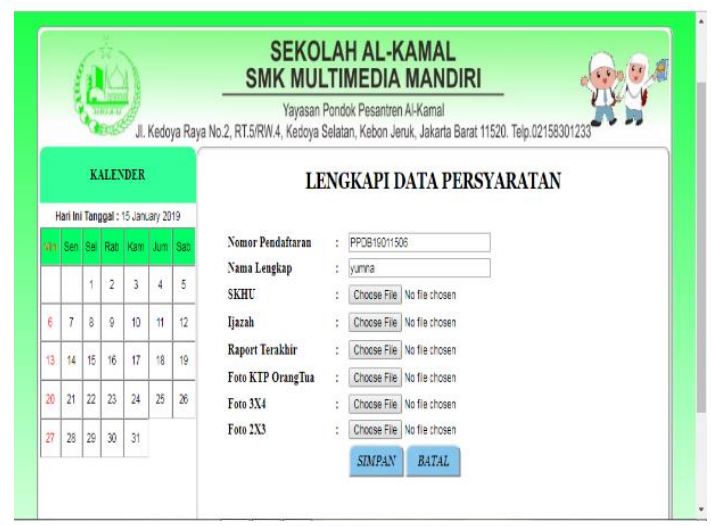

Gambar 12. Halaman upload persyaratan

\section{Testing (Pengujian)}

Tahapan selanjutnya adalah melakukan pengujian menggunakan BlackBox Testing pada sistem informasi pendaftaran siswa baru yaitu dengan melakukan uji validasi masukan dan keluaran dari sistem.

1. Pengujian Halaman Pendaftaran

Tabel 1. Blackbox testing Halaman Pendaftaran

\section{No. Rancangan Proses Hasil Yang Hasil Diharapkan}

\begin{tabular}{lllll}
\hline 1 & $\begin{array}{l}\text { Mengisi data calon } \\
\text { siswa secara lengkap }\end{array}$ & Data tersimpan & sesuai \\
2 & $\begin{array}{l}\text { Mengisi data tidak } \\
\text { lengkap }\end{array}$ & $\begin{array}{l}\text { Sistem } \\
\text { memberikan } \\
\text { pesan }\end{array}$ & sesuai \\
& & & \\
& & & "silahkan \\
& & & \\
& & & \\
\hline
\end{tabular}

2. Pengujian Halaman Login calon siswa

Tabel 2. Blackbox testing Halaman Login calon siswa

\begin{tabular}{|c|c|c|c|}
\hline No. & Rancangan Proses & $\begin{array}{c}\text { Hasil Yang } \\
\text { Diharapkan }\end{array}$ & Hasil \\
\hline 1 & $\begin{array}{c}\text { Masukkan } \\
\text { Username dan } \\
\text { password dengan } \\
\text { benar }\end{array}$ & $\begin{array}{c}\text { Masuk ke } \\
\text { halaman home } \\
\text { siswa }\end{array}$ & sesuai \\
\hline 2 & $\begin{array}{c}\text { Username dan } \\
\text { password yang } \\
\text { dimasukkan salah }\end{array}$ & $\begin{array}{c}\text { Sistem } \\
\text { memberikan } \\
\text { pesan "username } \\
\text { dan password } \\
\text { salah, silahkan } \\
\text { login kembali" }\end{array}$ & sesuai \\
\hline 3 & $\begin{array}{l}\text { Username atau } \\
\text { password Kosong }\end{array}$ & $\begin{array}{c}\text { Sistem } \\
\text { memberikan } \\
\text { pesan "username } \\
\text { atau password } \\
\text { tidak boleh } \\
\text { kosong" }\end{array}$ & sesuai \\
\hline
\end{tabular}




\section{E. Software Increment (Peningkatan Perangkat Lunak) \\ $F$.}

Setelah dilakukan Implementasi terhadap sistem informasi pendaftaran siswa baru berbasis web, kemudian akan dilakukan kegiatan monitoring dan evaluasi terhadap sistem yang diimplementasikan. Selanjutnya akan dilakukan pengembangan terhadap sistem dengan memperbaiki semua bug dan membuat sistem semakin lebih baik untuk digunakan kedepannya. Menambahkan sistem menu baru kedalam sistem dapat dilakukan misalnya dengan mengembangkan sistem informasi akademik maupun sistem pemantauan absensi kesiswaan.

\section{KESIMPULAN DAN SARAN Kesimpulan}

Pengembangan sistem informasi pendaftaran siswa baru berbasis Web menggunakan metode extreme Programming $(x p)$ merupakan salah satu solusi yang tepat bagi SMK Multimedia Mandiri Jakarta. Dengan mengimplementasikan sistem informasi pendaftaran siswa baru secara online dapat menjangkau siswa dari luar daerah karena proses pendaftaran yang efektif dan efisien. Selain itu bagi panitia seleksi akan mempercepat proses pembuatan laporan penerimaan siswa baru.

\section{REFERENSI}

Candra, B. A., Muludi, K., \& Irawati, A. R. (2013). Rancang Bangun Sistem Informasi Manajemen Terpadu ( SIMANTEP) Online PT . PLN ( Persero ) Sektor Pembangkitan Tarahan Lampung Dengan Metode Extreme Programming. Jurnal Komputasi, 1(1), 3142.

Eviani, S., Rizki, S. D., \& Pratiwi, M. (2016). Sistem Informasi Penerimaan Siswa Baru Berbasis Web Pada Smpn 34 Kabupaten Tebo. Jurnal Teknologi, 6(1 ISSN : 23014474), 13-19.

Fatimah, S., Setiawan, I., \& Pantjarani, A. (2016).
Rancang Bangun Sistem Pendaftaran Informasi Penerimaan Peserta Didik Baru Berbasis Online. Jurnal MIHB, 3(1), 283291.

Fatoni, A., \& Dwi, D. (2016). Rancang Bangun Sistem Extreme Programming Sebagai Metodologi Pengembangan Sistem. Prosisko, 3(1), 1-4. Retrieved from http://ejurnal.lppmunsera.org/index.php/PROSISK O/article/view/116

Mulyani. (2016). Metode Analisis dan Perancangan Sistem.

Putri, L. D. (2014). Perancangan Sistem Informasi Penerimaan Siswa Baru Pada Sekolah Menengah Kejuruan Negeri 3 Pacitan. Indonesian Journal on Networking and Security, 3(4 ISSN : 2302-5700), 2-5.

Ruhul Amin, M. K. (2017). Rancang Bangun Sistem Informasi Penerimaan Siswa Baru pada SMK Budhi Warman 1 Jakarta. Jurnal Ilmu Pengetahuan Dan Teknologi Komputer, 2(2 E-ISSN: 2527-4864), 113121.

Sukamto, R. A., \& Shalahudin, M. (2013). Rekayasa Perangkat Lunak Terstruktur dan Berorientasi Objek. Bandung: Informatika.

Supriyatna, A. (2018). Metode Extreme Programming Pada Pembangunan Web Aplikasi Seleksi Peserta Pelatihan Kerja. Jurnal Teknik Informatika, 11(1), 1-18. https://doi.org/10.15408/jti.v11i1.6628

Witanto, R., \& Solihin, H. H. (2015). Perancangan Sistem Informasi Penerimaan Siswa Baru Berbasis Web ( Studi Kasus : Smp Plus Babussalam Bandung ). Jurnal Teknologi Informasi Dan Komunikasi, 1(1), 54-63.

https://doi.org/https://doi.org/10.1234/jtik.v $6 \mathrm{i} 2.107$ 